\title{
Changing Power of Union in India: A Study of Actors' Perception
}

\author{
Dr. Manoranjan Dhal \\ Assistant Professor, OB \& HR Area, Indian Institute of Management Kozhikode, Kozhikode, \\ Kerala, India
}

Tel- 91-495-2809441, Email: manoranjan@iimk.ac.in

Accepted: October 28, $2011 \quad$ Published: November 27, 2011

doi:10.5296/ijhrs.v1i2.1117 URL: http://dx.doi.org/10.5296/ijhrs.v1i2.1117

\begin{abstract}
With the growing globalization of market, out sourcing of production, and downsizing of manpower trade unions are losing their power across the globe. This paper tries to explore the perception of actors, i.e. workers, trade union leaders and managers about the changing power structure of union. Attempt was made to study the perception of actors about the function of union, industrial relations climate and its impact on power of union. This study is based on 640 structured interviews conducted in manufacturing industries across different sectors in India.
\end{abstract}

Keywords: $\quad$ Actors; Trade Union; Union Power

\section{INTRODUCTION}

Globalization of market, outsourcing of product, adoption of LEAN manufacturing system, flat organizational structure, use of information technology, and growth of highly educated new generation of employees have forced the trade unions to lose membership across the globe. But, at micro level unions were unable to fulfill the need of the workers and the proactive HR practices adopted by the management have posed challenges to the members' affiliation towards union. The union leaders were not effective enough to prepare the future strategy and motivate the workers to continue with the union. The major actors of industrial relations i.e. workers, union leaders and management have adopted several strategies to survive and grow. The other actor government is playing more of a laissez faire role as there is not much change to the labour policy and amendment to the labour law in India since decades. This paper tries to explore the perception of workers, managers, and trade union 
leaders about the function of union, industrial relations climate, HR practices and union power. It also tries to find out the impact of union characteristics, industrial relations climate, and HR practices on union power.

\section{REVIEW OF LITERATURE}

Trade unionism has been the focus of research for several years and determine the strength and weakness of the union. The function of trade union, its leadership, affiliation with the political parties has not only influenced the growth, but also determined the power of trade union.

\section{Trade Union Function}

The National Commission on Labour defined the functions of unions as to secure fair wages for workers, safeguard security of tenure and improve conditions of service, enlarge opportunities for promotion and training, and improve working and living conditions. The other functions of the union include providing for educational, cultural and recreational facilities, co-operating and facilitating technological advances, promoting identity of interests of the workers with industry, offering responsive co-operation in improving productivity, discipline and high standard of equality, and promoting individual and collective welfare (Pilli, 2000).

Majority of the studies such as Sinha and Paul (1963), Vaid (1965), Arya (1982), Ramaswamy (1977), Gani (1988), Bhangoo (1989), Cheema (1990), Pandey and Vikram (1969) indicate the economic and security motives are the most important factors for unionization. Similarly studies by Sheth (1969), Foneseca (1965), Crouch (1966), Pande and Vikram (1969), Das (1985), Monga (1978), and Dayal and Sharma(1970) also show that poor leadership, fear of victimization, multiplicity of unions are the causes for lack of workers' participation in union activities.

Singh (1980) pointed out that workers, managers and union leaders differ among themselves regarding the objectives of a union. Though maintaining discipline among workers is considered to be an important function of the trade union, it was found that unions failed to discipline workers, and there were many incidents of violence by workers against the management and owners of industry. Modi (1995) while studying the unionism in Punjab Road Transport Corporation found the union leaders were perceived as facilitating the redressal of workers' routine grievances, securing better wages, bonus, fringe benefits, etc. Educating workers regarding their rights and duties was an important function of the union. Most of the union leaders favoured the participation of outside leaders in union activities. Unions were found to be effective in protecting workers from victimization by the management. Leaders were not competent enough to run the union effectively. Workers and union leader's perception regarding the functions of union were more or less similar. But workers condemned the practice of political affiliation as well as multiplicity of unions. Management felt that existence of union was essential to protect the interests of workers. Multiple union structures were found to be more advantageous to management than a single union. Union leaders adopted numerous unfair labour practices, and extracted personal 
favours from the management. Union experience has a negative impact on the job satisfaction of union members and non-members (Artz, 2010)

\section{Union Leadership}

For the purpose of this study the office bearers of a union (includes the outsiders) were considered leaders of the union, because they are either elected or nominated and represent the workers, who are members of the union.

\section{Leadership Quality}

The trade union leaders were always blamed for their lack of vision. The new breed of trade union leaders of fragmented unions have no conception of trade unionism as a movement but only focus on the immediate monetary gains of their members and on extending their field of influence and power. They routinely used muscle power to terrorise employers and rival trade unions (Tulpule, 1990). Subramanian and Rao (1997) while studying the attitude of trade union leaders found that leaders were willing to assume an equal responsibility along with the management in implementing the following activities - maintaining good relationship between unions and management; educating workers on accident-free and safe work methods; maintaining discipline within the mill; educating workers on their duties and responsibilities; solving problems arising among workers; being more appreciative and accommodative in dispute resolution, and controlling absenteeism.

\section{Leaders' commitment and competency}

Leaders must be committed to the cause of workers and competent also to handle workers' problems and develop good relations with the management without any bias. Patel (1998) while discussing the problem of industrial workers in Mumbai revealed that lockouts and secret deals with the Shiv Sena unions have put the employees' unions on the defensive. Thus, union leaders were considered as loyal neither to the union not to the workers.

\section{Political Affiliation}

Trade union is a political body and represents a political system with a philosophy of the workers economy (Das, 1990). But Rao (1986) found that most of the union leaders are democratic in their functioning and their degree of involvement in politics is not significant. However, Zullo (2008) found that organized labour stimulates political participation and influence the electoral choice which reflects the high political affiliation of union.

Political unionism was found as a contributory factor for the development and strength of trade union movement (Bograte, 1970). But Singh (1990) held politicization of unions responsible for creating an adversarial effect on trade union consciousness. Thakur and Munson (1969) while analyzing the political character of unions brought out the positive role of outside leadership in guiding several unions. Authors like Reddy (1972), Ashraf (1974), Aziz (1974), Crouch (1966), Pattabhi (1967), Ramanujam (1967), Ramaswamy (1977), Chatterji (1980) and Mamkoottam (1982). Karnik (1966) observed that the presence of outsiders in unions has not only increased the political domination of unions but also led to inter-union and intra-union rivalries, and disrupted the industrial harmony. 
Industrial Relations Climate

2011, Vol. 1, No. 2

In the Industrial Relations System, management and trade unions compete for dominance over each other, and in the process try to get the support of workers and the government. Collective bargaining and worker's participation in decision-making are the playing field, and the nature of labour laws and labour policies acts as a catalyst. The industrial disputes, the settlements signed, and the man days lost is the determinants of the prevailing industrial relations climate. Depending on these practice industrial relations climate can take the form of confrontation, communication, cooperation or consultation.

Industrial relations climate can be defined as the degree to which parties have respect for each other's goals and settle problems jointly (Deery, Erwin, \& Iverson, 1999). But 'industrial relations climate' has commonly been used to describe the quality of labour management relations in the organization (Katz, Kochan, \& Gobeille, 1983).

Dastmalchian, Adamson and Blyton (1986) define industrial relations climate is an estimate of union-management cooperation, mutual regard, apathy, joint participation, trust/fairness, and hostility/aggression.

Angle and Perry (1986) found that industrial relations climate is strongly associated with commitment of workers towards the trade union as well as the management. A cooperative industrial relations climate had positive effects on organizational commitment, but negative effects on union loyalty (Deery, Erwin, \& Iverson, 1994). Where employees perceive managerial attitudes are favourable to unions, they are more likely to report a more positive industrial relations climate (Pyman et. Al 2010)

\section{Cooperation}

Workers as a stakeholder of the business have every right to know about those forces, which compelled the management to adopt such strategies. The workers can ask whether adequate steps are taken by the management to save their jobs before going for lay-off, retrenchment, voluntary retirement, or closures.

There is a need for greater transparency in management and trade union functioning resulting in better relationship. Management practices such as total quality management, quality circles, kaizen, quality of work life programmes have provided better participation and greater interaction of workers with the management. The nature and scope of participation has inversed considerably and they feel a part of the organization.

Union leaders are of the view that trade unions are not averse to contribute to the prosperity of the business where their members are provided with secured jobs. But they are left with no option but to limit their activities to protect the interests of members only, as in other areas, the involvement of trade unions have not been encouraged. The trade unions have always been keen to cooperate with the employers and they believe that it is the employers who have to come forward to create an environment for the trade unions to reciprocate (Sinha, 2001).

This team-based work structure has resisted unionization or union strategic 
involvement (Heckscher \& Schurman, 1997).

\section{Confrontation}

Even after years of changes, conflict between labour and management is common and often results in violence, inflicting intolerable hardships on society. While studying strikes as a form of conflict, Pattnaik (1993) found that multi-union plants are more prone to strike than single union plants.

Trade unions are supposed to cooperate as well confront at times with the management to get a larger slice for the labour. But trade unions are accustomed to arguing that the management's job is to manage, while their job is to oppose (Ramaswamy, 1999).

\section{Communication}

Guest (1989), and Purcell (1991) were of the view that the introduction of employee involvement programmes and the application of more extensive forms of information-sharing is associated with attempts to marginalize unions and reduce their capacity to mobilize industrial action. A closer communication of interests between the labour and the management would lead to a culture of high performance. For that, the workers should be fully informed about the company, including investment, size, the nature of its business, the products, the services, labour policies, and the profit or loss position, etc (Mital, 2001).

\section{Consultation}

Sinha (2001), Secretary, INTUC was of the view that workers are still treated as commodity, and behaved with indignity. They are never taken into confidence, nor have their rights at the workplace been recognized. However, of late, employers and their associations started a consultation process with trade unions. Trade unions have been struggling for greater participation of workers in management, but the response from employers was not positive indicating their lack of interest in accepting trade unions as social partners. For effective implementation of Voluntary Retirement Scheme (VRS), full transparency is required in consultation with workers to increase their confidence.

\section{Changing Power Dynamics}

\section{Union Power}

'Collective bargaining' is a forum where both the management and the union tussle for power thorough cooperation as well as confrontation. 'Bargaining power' is defined as the ability to secure another's agreement to one's own terms (Chamberlain \& Kuhn, 1965). Goodman (1989) found that employer attitude towards trade union representatives has become more assertive, and management was trying to develop direct communication links with workers, and improve the flow of information.

Collective bargaining is primarily based on power dynamics. Non-sharing of information and pressure tactics are potent weapons in the hands of the employers and unions (Bhattacherjee, 1999). 
A person may be said to have power to the extent that he influences the behaviour of others in accordance with his own intentions (Mamkoottam, 1982). In other words, power resides implicitly in another person's dependency. Unions have lost strength, power, and significance in the current economic situation. Workers were driven by the whims and compulsions of employers; governments were unable to deal with grave socio-economic consequences of falling employment levels; unions and workers became the victim of the new economic order (Sheth, 2001). The sources of union power include employer patronage, recruitment loyalties, concentration on ethnic identities, political parties, external intermediaries, workers, union fund, size of industry union, state apparatus, and muscle power (Masilamani, 1993).

Management is competing with trade unions for the allegiance of the workforce (Guest \& Dewe, 1991). Wining over the bargaining table depends upon the temporary positional power of either party. Job insecurity is also accompanied by a reduction in perceived union support and lead to intension of resigning membership (Witte et al.2008) adding to the loss of union power.

\section{Management}

Management is said to possess control power (Masialmani, 1992), or ownership power (Finkelstein, 1992) by virtue of ownership and control over factors of production. The management also possesses position power (Fielder, 1967), or structural power (Finkelstein, 1992) like right to hire and fire.

Sometimes employers are also found to be more powerful than the union leaders. Studies made by Mamkootam (1977), and Sherlock (1989) revealed that the employer had the ability to repress militant trade unionism and force trade union leaders into accepting the employer's terms for recognition.

The author proposes the following conceptual model for the purpose of understanding this study (See Figure 1).

\section{Methods}

A five-point (Likert type) multi-dimensional scale was used for the sake of uniformity in measuring all the variables under study. The data were subjected to factor analysis technique to define the constructs, and establish the validity of the dimensions. It was decided to include only those items in a factor that had a loading of $\geq 0.30$. The highest absolute value of the loading was taken into account for inclusion of an item into a factor. It was further decided to go for 'second order' forced factor analysis in order to reduce all the derived dimensions. The assumption taken into consideration for carrying out the factor analysis was that the data matrix has sufficient correlations (greater than .30) among variables (Hair, Anderson, Tatham, \& Black; 1995). 
Figure 1: Conceptual model of the study

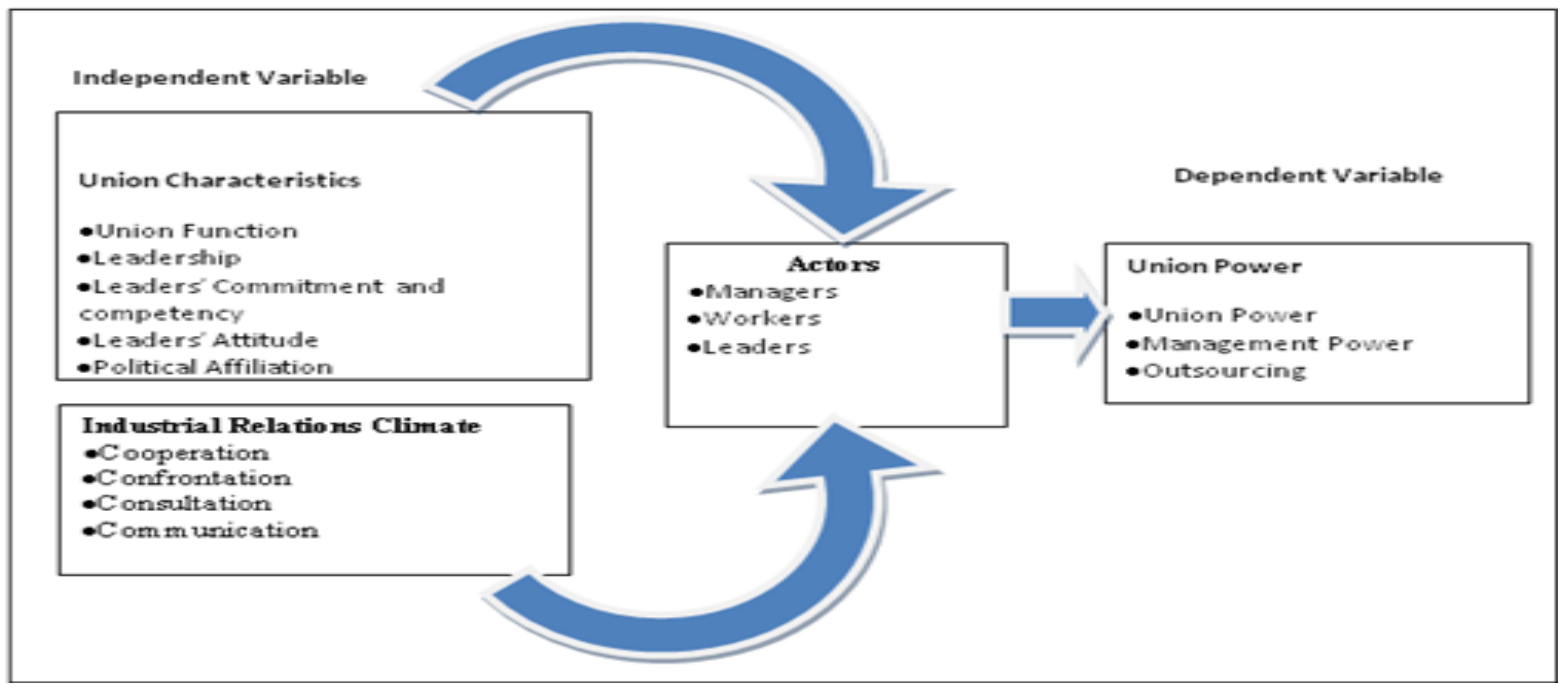

All the variables in the study were factor analysed using principal component with varimax rotation, as all these variables appeared to be interrelated with each other. However, before proceeding for factor analysis, a test of normality was performed for all the variables using Kolmogorov-Smirnov test (Hair, Anderson, Tatham, \& Black; 1995). The results showed that data for different variables included in this study followed a normal distribution. The highest loading against any factor was taken into account as a representative of that scale showing the construct validity of the scale. A summary of the tool characteristics and the reliability score of the scales are reflected in table 1.

Table 1: Summary of tool characteristics

\begin{tabular}{|c|l|c|c|c|c|c|}
\hline $\begin{array}{c}\text { Serial } \\
\text { No. }\end{array}$ & \multicolumn{1}{|c|}{ Variable } & $\begin{array}{c}\text { No. of } \\
\text { Items }\end{array}$ & $\begin{array}{c}\text { Theoretic } \\
\text { al Range }\end{array}$ & MEAN & SD & $\begin{array}{c}\text { Alpha } \\
\text { Coefficient }\end{array}$ \\
\hline 1 & $\begin{array}{l}\text { Union } \\
\text { Characteristics }\end{array}$ & 26 & $26-130$ & 84.14 & 17.52 & .90 \\
\hline 2 & IR Climate & 24 & $24-120$ & 78.80 & 14.75 & .89 \\
\hline 3 & Union Power & 12 & $12-60$ & 38.81 & 7.99 & .79 \\
\hline
\end{tabular}

The factors obtained from this analysis for all the scales were subjected to further statistical analysis. Summary of the factor analysis results for different scales are presented in table 2.

\section{Scale for Union Characteristics}

This 26-item scale on union characteristics was treated with factor analysis resulting in five distinct factors. The factors confirmed the dimensions, which were set up on the basis of the literature survey. Thus, factors representing the union characteristics were identified to be the function of the union, union leadership, union leaders' commitment and competency, political affiliation, and leaders' attitude towards management as well as the job.

The measure of the function of union presented in the study is mostly adopted from the scale developed by Modi (1995) to revaluate the nature of the functioning of the union in 


\section{I Macrothink}

International Journal of Human Resource Studies

ISSN 2162-3058

2011, Vol. 1, No. 2

the changing environment (5 items) and one item was adopted from the study by Parmar (1997) to study the reason behind worker's joining the trade union. Two items were added to the scale basing on the pilot study.

Four items were adopted from a study by Modi (1995) and modified for use in this study the to measure union leadership. One item was adopted from a scale by Subramanain and Rao (1997) to study the quality of union leadership where as tow items were developed to study of commitment of union leader. Union leaders' commitment and competency, and their attitude towards management( three items) were also put into test as it was perceived that leaders lack commitment (Patel, 1998) and have a negative attitude towards management (Sood, 1984).

Political affiliation of union being the important characteristics of Indian trade union, items were developed to study its need in the changing economic scenario (three items) basing on the controversial findings by several researchers (Rao, 1986; Bograte, 1970; Singh, 1990; Ramaswamy, 1977; Karnik, 1966; and Mamkoottam, 1982).

Table 2: Summary of factor analysis for scales.

\begin{tabular}{|c|c|c|c|}
\hline Factors & Eigen values & $\begin{array}{c}\text { Variance } \\
\text { explained }(\%)\end{array}$ & $\begin{array}{l}\text { Total variance } \\
\text { explained }(\%)\end{array}$ \\
\hline Union Characteristics & & & \\
\hline Function of union & 9.31 & 35.82 & \multirow{5}{*}{59.86} \\
\hline Union leadership & 2.57 & 9.87 & \\
\hline Leaders' commitment and competency & 1.51 & 5.81 & \\
\hline Political affiliation & 1.15 & 4.41 & \\
\hline Leaders' attitude & 1.03 & 3.95 & \\
\hline \multicolumn{4}{|l|}{ Industrial Relations Climate } \\
\hline Union Cooperation & 6.93 & 28.87 & \multirow[t]{5}{*}{57.36} \\
\hline Consultation & 2.55 & 10.64 & \\
\hline Management Cooperation & 1.67 & 6.97 & \\
\hline Confrontation & 1.33 & 5.54 & \\
\hline Communication & 1.28 & 5.34 & \\
\hline \multicolumn{4}{|l|}{ Union Power } \\
\hline Union power & 3.75 & 31.21 & \multirow[t]{3}{*}{49.96} \\
\hline Management power & 1.18 & 9.81 & \\
\hline Outsourcing & 1.07 & 8.94 & \\
\hline
\end{tabular}

\section{Scale for Industrial Relations Climate}

The industrial relations climate in Indian organizations can be characterized by four factors, such as cooperation, confrontation, communication and consultation. These dimensions were defragmented into relevant items for construction of a scale. A ten-item scale used by Deery, Erwin \& Iverson (1999) to measure the industrial relations climate in 
U.K. was available for the use. But, this scale consisted of concept like joint management-union committee was not prevailing in Indian organizations. There were also several other scales on industrial relations climate by researchers such as Huszczo and Hoyer (1994), Dastmalchian, Adamson, and Blyton (1986) which takes into account the aspects like use of power by union to resolve conflicts, and joint decision-making process which are not prevalent in Indian scenario preventing to adopt the scale. However by taking cue from the above studies the present scale on industrial relations climate was developed. Most of the researchers had used industrial relations climate as dependent variable, and some as predictor of organizational and union commitment (Deery, Erwin, \& Iverson, 1994). But, here industrial relations climate was used as a predictor of the union power.

When all the 31 items were subjected to factor analysis, five factors were extracted. These factors were identified as confrontation, consultation, communication, cooperation from management and cooperation from union.

The Items used for evaluating the industrial relations climate was based on the literature but different from the items used by several researchers (Huszczo and Hoyer, 1994; Deery, Erwin, \& Iverson, 1999, and Katz, Kochan, \& Gobeille, 1983). Two items were adopted from the scale sued by Huszczo and Hoyer (1994) to study the cooperative relationship between union and management, but modified for Indian environment before.

\section{Scale for Union Power}

Factor analysis results showed the emergence of three distinct factors from 12 items, which were identified as union power, management power, and outsourcing and explained 49.96 per cent of variance.

Another major aspect, which affected the power of the union is casualization of workers. All these items were developed basing on the literature and pilot study to examine the power dynamics of union and management (Seth, 1993; Ramaswamy, 1988; Sengupta, 1992; and Nulty, 1993). So the changing power dynamics was considered as a dependent variable for the study.

\section{Sample}

The sample consisted of six hundred forty respondents form seven manufacturing organizations of Orissa, India. The study included 317 workers, 107 union office-bearers (leaders), and 216 managers.

All the seven organizations finally selected for the study represented diverse sectors. This heterogeneity was maintained to give proper representation of each sector and future generalization of the outcome. The heterogeneity can be well read from Table 3.

While collecting data, it was taken care that workers from all functional departments including the service departments are included. Similarly, managers from different levels were also covered. Trade unions from different political affiliation and different ideologies also participated in the study. Recognition was not the criteria for the selection of the union, and almost all the registered trade unions were contacted to give their response. Trade union office bearers who were outsider to the plant, but closely associated with the functioning of 
the union were also asked to give their opinion.

Table 3: Summary of sample characteristics

\begin{tabular}{|c|c|c|c|c|c|}
\hline \multirow{2}{*}{$\begin{array}{c}\text { ORGANIZAT } \\
\text { ION No. }\end{array}$} & \multirow{2}{*}{$\begin{array}{l}\text { Industrial } \\
\text { Categorization }\end{array}$} & \multicolumn{3}{|l|}{ Respondents } & \multirow{2}{*}{ TOTAL } \\
\cline { 3 - 5 } & Worker & Leader & Manager & \\
\hline 1 & Steel & 51 & 17 & 34 & 102 \\
\hline 2 & Chemical & 50 & 11 & 30 & 91 \\
\hline 3 & Power & 51 & 20 & 30 & 101 \\
\hline 4 & Aluminum & 48 & 23 & 38 & 109 \\
\hline 5 & Engineering & 41 & 20 & 22 & 83 \\
\hline 6 & $\begin{array}{c}\text { Refractory Products } \\
\text { Manufacturing }\end{array}$ & 46 & 5 & 29 & 80 \\
\hline 7 & Paper & 30 & 11 & 33 & 74 \\
\hline & ToTAL & $\mathbf{3 1 7}$ & $\mathbf{1 0 7}$ & $\mathbf{2 1 6}$ & $\mathbf{6 4 0}$ \\
\hline
\end{tabular}

The average age of worker was 40 years $(\bar{X}=39.90)$ and the majority of them were having qualification above $10^{\text {th }}$ class and/or diploma in engineering (Mode $=2$, representing the category). The union leaders also belonged to the same age group ( $\bar{X}=42.71$ ) with similar qualification. The average age for managers were $42(\bar{X}=42.16)$, where as the majority of them were having qualification of post graduation or engineering degree. It was found that the age of the respondents was normally distributed (Kolmogorov-Smirnov Z). The average length of union membership of the workers and leaders was 11 years. The average length of assuming the union leadership was 8 years.

In order to avoid the biasness on the part of respondents they were fully convinced that their identities would be kept confidential. Even the questionnaire was kept free from name of the respondents though their biographical data were collected. Since the trade union is an issue of major concern in present market scenario; the organizations identity were also kept confidential. The major objective of this study was to explore the relationship between a set of 'independent variables' namely union characteristics, industrial relations climate, and a 'dependent variable' union power. The study was conducted in an exploratory framework to examine the strength of relationship among the variables as well as differences between the actors (managers, union leaders, and workers). Data were collected from workers, union leaders, and managers to examine their perception. The actors were considered as a control variable in the study.

The data were subjected to statistical analyses for drawing inferences. Data were analysed 
using statistical package for social sciences 16.0 (SPSS) for windows. All the variables were treated as multidimensional in nature. Multiple Regression Analysis (MRA) and Multivariate Analysis of Variance (MANOVA) were used to examine the strength of relationship among the variables, and differences among the perception of actors.

\section{RESULT AND DISCUSSION}

Research proposition 1: Workers, managers and union leaders perceive the functioning of union, union leadership, leaders' commitment and competency, political affiliation of union and union leaders' attitude towards management differently.

Table 4: Summary of multivariate analysis of variance (MANOVA) with regard to attitude of actors in public and private sector on union characteristics

\begin{tabular}{|cccccc|}
\hline Source & $\begin{array}{c}\text { Depende } \\
\text { nt Variable }\end{array}$ & $\begin{array}{c}\text { Sum of } \\
\text { Squares }\end{array}$ & df & $\begin{array}{c}\text { Mean } \\
\text { Square }\end{array}$ & F \\
\hline ACTOR & UF & 5469.51 & 2 & 2734.75 & $50.00^{* *}$ \\
& UL & 4631.77 & 2 & 2315.88 & $59.83^{* *}$ \\
& ULCC & 218.44 & 2 & 109.22 & $16.89^{* *}$ \\
& PA & 230.80 & 2 & 115.40 & $13.34^{* *}$ \\
& ULA & 414.70 & 2 & 207.35 & $41.81^{* *}$ \\
\hline
\end{tabular}

** Significant at .01 level

Abbreviations Used: UF - Union Function, UL - Union Leadership, ULCC - Union Leaders' Commitment and Competency, PA - Political Affiliation, ULA - Union Leaders' Attitude

The results shown in Table 3.1 reveal that workers, managers and union leaders differed in their perception with regard to function of the union $(\mathrm{F}=50.00, \mathrm{p}<.01)$, union leadership ( $\mathrm{F}=59.83, \mathrm{p}<.01)$, leaders' commitment \& competency $(\mathrm{F}=16.89, \mathrm{p}<.01)$, political affiliation $(\mathrm{F}=13.34, \mathrm{p}<.01)$, as well as leaders' attitude towards the management $(\mathrm{F}=41.81, \mathrm{p}<.01)$.

The results showed that the trade union leaders rate the functioning of the union as high $(\bar{X}=37.60)$ compared to managers $(\bar{X}=29.76)$ and workers $(\bar{X}=29.12)$. This shows that unions did not function up to the expectation of the workers and the managers. Due to this workers bypass the union and union leaders. The findings are consistent with the studies of Modi (1995), Arya (1982), Gani (1988), Bhangoo (1989), and Cheema (1990), 
which indicate the workers' apprehension about union's contribution towards member's welfare.

The actors also differed on issues like union leadership, leaders' commitment and competency as well as leaders' attitude towards management. Union leaders perceived themselves more successful in their functioning $(\bar{X}=27.86)$, compared to the managers $(\bar{X}$ $=19.91)$ and workers $(\bar{X}=20.59)$. Union leaders claim to maintain discipline among workers, and consult them before taking any vital decision. They also claim to be honest in utilizing the union fund and committed to the cause of the union as well as workers. But managers did not agree with leaders, and think them as the root cause of the industrial dispute. Managers perceived that union leaders are not mature enough to maintain the discipline and a better industrial relations climate to increase productivity.

Managers $(\bar{X}=12.70)$, trade union leaders $(\bar{X}=13.00)$, and workers $(\bar{X}=11.60)$ differed significantly in their perception on leaders' commitment and competency. It can be said that workers perceived a lack of commitment among the leaders, and they have become puppets, while managers think that leaders are committed and competent enough to carry out their jobThe result is consistent with the earlier findings that uniona leaders are not competent (Modi 1995). They are selfish and motivated by personal interest. Managers also agreed on this point with workers, but union leaders had a different view. Modi (1995) also found that union leaders were not committed to the cause of workers. Workers were not satisfied with the leaders, as they were neither consulted in decision-making process, nor in preparing the agenda for bargaining.

There was a significant difference in perception among managers, union leaders' and workers on union leaders attitude towards management and job. Workers and managers agreed to the fact that union leaders neglected job responsibility and had a close mindset towards management, but leaders did not accept this. This study revealed that there was significant difference among the actors regarding political affiliation of the union. The workers $(\bar{X}=10.41)$ and the union leaders $(\bar{X}=10.88)$ strongly supported the affiliation of trade unions with political parties, as they were dependent on them to fulfill their demands. They also considered the presence of outside leaders in union activities as a crucial factor. Their primary concern for having a political link was that it would provide a strong bargaining power and a representation in the government. Both workers and leaders considered management as more powerful and exploitative, and the political power can countervail them. These findings are not in congruence with the observations made by Modi (1995) that workers are against the political linkage, because such relationship causes fragmentation of the trade union. But the managers did not consider the political affiliation of unions $(\bar{X}=9.26)$ a necessary factor in their effective functioning. 
Actors differed in their perception due to their varied interest. Union leaders are functioning on the false premise of fulfilling workers' interest, and are victimized by the anti union strategies of the management. Workers wanted the presence of the union, but are not satisfied with the union leadership, their commitment, and competency. Workers at the one end want job security, and on the other hand, look for better financial benefits, and personal growth. Management is also trying to maintain a direct relationship with workers by adopting better human resource policies and practices.

Research Question 2: Is there a difference in the perception of actors with regard to industrial relations climate?

Table 5: Summary of multivariate analysis of variance (MANOVA) about the perception of actors in public and private sector regarding industrial relations climate.

\begin{tabular}{|cccccc|}
\hline Source & $\begin{array}{c}\text { Depende } \\
\text { nt Variable }\end{array}$ & $\begin{array}{c}\text { Sum of } \\
\text { Squares }\end{array}$ & df & $\begin{array}{c}\text { Mean } \\
\text { Square }\end{array}$ & F \\
\hline ACTOR & UNC & 825.88 & 2 & 412.94 & $20.78^{* *}$ \\
& CU & 918.58 & 2 & 459.29 & $24.83^{* *}$ \\
& MC & 2.28 & 2 & 1.14 & .09 \\
& CF & 536.54 & 2 & 268.27 & $20.69^{* *}$ \\
& COM & 529.49 & 2 & 264.75 & $21.66^{* *}$ \\
\hline
\end{tabular}

** Significant at .01 level

Abbreviation Used: UNC - Union Cooperation, CU - Consultation of Union, $M C$ Management Cooperation, CF - Confrontation, COM - Communication

Cooperation from the union to maintain union-management relationship also differed significantly $(\mathrm{F}=20.78, \mathrm{P}<.01)$ as reflected in their mean score (managers, $\overline{\mathrm{X}}=17.68$; union leaders, $\bar{X}=15.42$; and workers, $\bar{X}=15.14)$. Union leaders claimed that they helped in maintaining a better industrial relations climate and workers also supported it. Leaders helped the management in solving the problems of the organization, and cooperated with them during the process of bargaining. This finding contradicts an earlier finding by Modi (1995) that union leaders prefer a confrontative climate in securing a better deal for workers. They feel that unless a strike call is given, management did not attend to their demands and problems. It was surprising to find that managers claimed of getting better cooperation from union compared to the perception of union leaders and workers.

There was significant difference among the perception of actors regarding the consultation of union by the management in policy matters $(F=24.83, p<.01)$ as reflected in 
their mean score (managers, $\overline{\mathrm{X}}=19.72$; union leaders, $\overline{\mathrm{X}}=23.26$; and workers, $\overline{\mathrm{X}}=$ 21.66). The results showed that management did consult unions before taking any major policy decision, but it was not for participation in the decision-making, rather just passing information down the line. Though few organizations under survey had adopted voluntary retirement scheme as a measure of downsizing, unions were rarely consulted before implementation of the scheme. Unions were aware about the number of posts being abolished by the management. It was interesting to note that workers were readily accepting the voluntary retirement scheme and indirectly pressurizing the unions not to oppose it. One reason behind the acceptance of VRS was a lucrative compensation package.

There were no significant differences in opinions of managers, union leaders and workers on the issue of cooperation by the management to maintain a better industrial relations climate $(\mathrm{F}=.09, \mathrm{p}>.05)$. While managers $(\overline{\mathrm{X}}=13.11)$ claimed that they extended all possible cooperation to the union and the workers, leaders $(\bar{X}=13.28)$ and the workers $(\bar{X}=13.21)$ denied it. Managers were of the view that they did fulfill the demands of the workers, extended welfare facilities, resolved their grievances, and even helped the unions in its functioning. Leaders were always welcome to discuss any problem with the management. But union leaders as well as workers were not satisfied with the effort of the management on welfare measures and grievance resolving. Due to the crisis in the market, organizations were withdrawing the non-statutory benefits to the workers. This had created a negative perception about the management among the workers. Study by Rao and Narayana (1992) in Indian Railways supports these findings that labour-management cooperation meant cooperation from the labour to the management and not vice-versa.

Actors' perception regarding a confrontative industrial relations climate varied significantly $(\mathrm{F}=20.69, \mathrm{p}<.01)$. The managers $(\overline{\mathrm{X}}=17.71)$ perceived the climate as more confrontative in nature compared to leaders $(\bar{X}=16.39)$, and workers $(\bar{X}=15.61)$. Managers were of the view that they never interfered in union matters. They tried to promote collective bargaining, and discussed the matters of common interest across the bargaining table. Managers also perceived that union leaders seldom cooperated with them during the process of bargaining. The result is consistent with the findings of Modi (1995) that managers perceive the presence of conflict as inevitable for maintaining a better union-management relationship. Unions were always at the receiving end on the bargaining table, which led to a confrontative climate. The trade union leaders had a different opinion about the issue of confrontation in workplace. They perceived that management patronized a particular union and created rivalry among unions. Though management favoured collective bargaining, but never disclosed the necessary information across the bargaining table, which hindered the process. Despite this, leaders extended their cooperation for a successful 
bargaining. Workers had a similar view about the prevailing industrial relations climate, as they strongly perceived that management created infighting among unions for its own interest, even tried to buy them out. Workers were not satisfied with the collective bargaining process, and felt that it will never help in improving the industrial relations climate.

Transparency in communication was considered to be an inevitable tool for creating a good industrial relations climate. The analysis showed that managers, union leaders, and workers differed significantly in their opinion over the communication process $(F=21.66, p$

$<.01)$. Managers $(\bar{X}=14.00)$ perceived that a proactive and effective communication system was operating within the organization. The financial performance of the organization was communicated to the unions as well as the workers. Workers were provided with proper feedback regarding the organizational requirement. Management also tried to establish a direct channel of communication with workers regarding operational matters. Union leaders

$(\bar{X}=12.66)$ considered that management was not communicating the required information about individual performance and organizational performance regularly. Regarding setting up of a bottom up communication channel, workers and union leaders admitted the failure of the management. Even in operational matters, it was difficult for a shop floor worker to interact with the manager. The workers $(\overline{\mathrm{X}}=11.91)$ did not get information from the management regarding the financial performance of the organization. There was a lack of proper feedback system, and it was also irregular. Workers were much concerned about the wages and welfare measures. Right to information was never the agenda of unions.

C. Research Question 3: Is the power dynamics of union perceived differently by the actors?

Table 6: Summary of multivariate analysis of variance (MANOVA) about perception of actors on union power.

\begin{tabular}{|cccccc|}
\hline Source & $\begin{array}{c}\text { Depende } \\
\text { nt Variable }\end{array}$ & $\begin{array}{c}\text { Sum of } \\
\text { Squares }\end{array}$ & df & Mean Square & F \\
\hline ACTOR & UP & 2069.82 & 2 & 1034.91 & $49.40^{* * *}$ \\
& OS & 302.13 & 2 & 151.06 & $30.22^{* * *}$ \\
& MP & 153.82 & 2 & 76.91 & $10.36^{* * *}$ \\
\hline
\end{tabular}

** Significant at .01 level

Abbreviations Used: UP - Union Power, OS - Outsourcing, MP - Management Power

There lies a significant difference in the perception of mangers, union leaders, and workers over the union power $(\mathrm{F}=49.40, \mathrm{p}<.01)$. Workers $(\overline{\mathrm{X}}=21.51)$ and union leaders $(\bar{X}=19.03)$ believed that union power has decreased in post-liberalized era. But the managers $(\overline{\mathrm{X}}=17.43)$ appear to be neutral on this issue. Workers and the union leaders 
believed that union membership is decreasing gradually. It may be due to the reduction in the workforce or innovative HR strategies of the management to gain the confidence of workers. It is now difficult on the part of the union to go for strike. Workers considered management as more powerful than unions. From the management point of view, the threat of strike from unions is always present.

There is a significant difference among managers, union leaders, and workers regarding outsourcing $(\mathrm{F}=30.22, \mathrm{p}<.01)$. It clearly shows that it is a matter of concern for all of them as number of casual workers has increased over the years. Managers $(\bar{X}=7.89)$ did not agree that casual labours are preferred over regular workers, as they are less likely to join the union, whereas union leaders $(\bar{X}=9.45)$, and workers $(\bar{X}=9.36)$ considered it as a tool of the management to weaken the union. It is a different issue that the law as well as the union does not protect casual labours. Casual labours that joined the union neither have the voting right to elect the office bearers, nor the union can raise an industrial dispute for them. It was also found that there were separate unions for contract labour under the same undertaking affiliated to same central federation. However, there is no doubt that casualisation has not only increased in organizations, but also has negatively affected the power of unions which is reflected in the perception of union leaders.

Management power has been perceived differently by the actors $(\mathrm{F}=10.36, \mathrm{p}<.01)$. There is a difference in the perception of managers $(\bar{X}=9.70)$, union leaders $(\bar{X}=10.37)$, and workers $(\bar{X}=10.83)$. Management wants to recognize a union and discuss all the matters of common interest with unions. But the union leaders and workers have a different view that management is trying to exploit them. Though lockout is considered to be a powerful tool to control workers' behaviour, it was found that most of the organizations under study had not faced any lockout during the past decade. Management is considered to be more powerful by the workers compared to the perception of union leaders. It can be inferred that the fear of victimization among the workers is more than the leaders.

\section{Research Question 4: Does union function, union leadership, leaders' commitment and competency, union leaders' attitude, political affiliation, industrial relations climate influence the union power?}

In order to test this hypothesis multiple regression analysis (MRA) was used. To assess the effect of predictors across organizations step-wise regression was used, which include the effect of control variables namely ownership and actors. The power dynamics was characterized by union power, management power, and outsourcing. The summery of the findings of multiple regression analysis is shown in table no 7.

The results showed that two union characteristics factors namely union leaders' commitment and competency $(\beta=-.29, \mathrm{p}<.01)$, and political affiliation $(\beta=.13, \mathrm{p}<.01)$, emerged as significant predictors for union power explaining 11 per cent of the variance in the criterion measure $(\mathrm{F}=16.95, \mathrm{p}<.01)$. The result is consistent with the findings that 


\section{Macrothink $\Lambda$ Institute"'}

leadership characteristics, union function, and communication system are responsible for union oligarchy (Mamkoottam, 1982). Ramaswamy (1977) was also of the view that political affiliation enhances the identity of the union. Union power was negatively predicted by union leaders' commitment and competency, but positively by political affiliation. Ownership $(\beta=.11, \mathrm{p}<.01)$, and actors $(\beta=.35, \mathrm{p}<.01)$ also had its impact on the power of the union. These factors explained 13 per cent of the variance in the criterion measure $(F=49.13, p$ $<.01)$. When these control variables were also included in the regression equation along with the independent measures, altogether it explained 20 per cent of the variance for the union power $(\mathrm{F}=23.82, \mathrm{p}<.01)$. Leaders' commitment and competency $(\beta=-.23, \mathrm{p}<.01)$, and political affiliation were the significant predictors for the union power $(\beta=.09, \mathrm{p}<.05)$.

While assessing the impact of industrial relations climate, it was found that consultation of union by management $(\beta=.21, \mathrm{p}<.01)$, and management cooperation $(\beta$ $=.22, \mathrm{p}<.01)$ had positive impact on union power, whereas confrontation $(\beta=-.13, \mathrm{p}<.01)$, and communication $(\beta=-.17, \mathrm{p}<.01)$ had a negative effect. These factors explained 9 per cent of variance in the criterion measure $(\mathrm{F}=23.23, \mathrm{p}<.01)$. Earlier findings provide evidence that a more co-operative climate is associated with enhanced union commitment (Deery, Iverson, and Erwin, 1994).

Table 7: Summary of regression analysis results incorporating independent measures as predictors and union power as criterion variable.

\begin{tabular}{|c|c|c|c|c|c|c|c|c|c|c|c|c|c|c|}
\hline \multirow[b]{3}{*}{$\begin{array}{c}\text { Predictor } \\
\text { Variable } \\
\end{array}$} & \multicolumn{14}{|c|}{ Criterion Variable } \\
\hline & \multicolumn{7}{|c|}{ UP } & \multicolumn{7}{|c|}{ OS } \\
\hline & B & $\begin{array}{c}\text { SE } \\
\text { B }\end{array}$ & $\beta$ & $\begin{array}{c}\text { Multiple } \\
\mathbf{R} \\
\end{array}$ & $\mathbf{R}^{2}$ & $\mathbf{R}^{2}$ & $\mathbf{F}$ & B & $\begin{array}{c}\text { SE } \\
\text { B }\end{array}$ & $\beta$ & $\begin{array}{c}\text { Multiple } \\
\text { R } \\
\end{array}$ & $\mathbf{R}^{2}$ & $\underline{\mathbf{R}^{2}}$ & $\mathbf{F}$ \\
\hline \multicolumn{15}{|l|}{ UC } \\
\hline UL & & & & & & & & .06 & .022 & $.19^{* *}$ & .29 & .09 & .08 & 11.97 *** \\
\hline ULCC & -.55 & .08 & $.29^{-}$ & .34 & .12 & .11 & $\begin{array}{l}16.9 \\
5 * * \\
\end{array}$ & -.23 & .037 & $.26^{-}$ & & & & \\
\hline PA & .216 & .07 & $.13^{* *}$ & & & & & & & & & & & \\
\hline Constant & $25.32 * *$ & & & & & & & $10.14 * *$ & & & & & & \\
\hline \multicolumn{15}{|l|}{ IRC } \\
\hline $\mathrm{UNC}$ & & & & & & & & -.13 & .025 & $\begin{array}{c}- \\
.26^{* *}\end{array}$ & .36 & .13 & .12 & $18.51^{* * *}$ \\
\hline $\mathrm{CU}$ & .22 & .05 & $21 * *$ & .31 & .10 & .09 & $\begin{array}{l}13.4 \\
7 * *\end{array}$ & .142 & .022 & $.28 * *$ & & & & \\
\hline $\mathrm{MC}$ & .30 & .06 & $.22 * *$ & & & & & .08 & .030 & $.13 * *$ & & & & \\
\hline $\mathrm{CF}$ & -.17 & .06 & $\begin{array}{r}- \\
.13^{* * *} \\
\end{array}$ & & & & & -.07 & .028 & $\begin{array}{r}- \\
.12^{* *} \\
\end{array}$ & & & & \\
\hline $\mathrm{COM}$ & -.23 & .06 & $\overline{-}^{-}$ & & & & & & & & & & & \\
\hline Constant & $17.54 * *$ & & & & & & & $8.67 * *$ & & & & & & \\
\hline
\end{tabular}

$* *$ = Significant at .01 level

$*$ = Significant at .05 level

\section{Continued ...}




\begin{tabular}{|c|ccccccc|}
\hline & \multicolumn{7}{|c|}{ MP } \\
\hline Predictor Variable & $\mathbf{B}$ & $\mathbf{S E ~ B}$ & $\boldsymbol{\beta}$ & Multiple R & $\mathbf{R}^{2}$ & $\underline{\mathbf{R}^{2}}$ & $\mathbf{F}$ \\
\hline UC & & & & & & & \\
\hline ULCC & -.18 & .044 & $-.17^{* *}$ & .24 & .06 & .05 & $7.97^{* *}$ \\
\hline PA & .13 & .039 & $.14^{* *}$ & & & & \\
\hline ULA & .11 & .051 & $.10^{*}$ & & & & \\
\hline Constant & $10.82^{* *}$ & & & & & & \\
\hline IRC & & & & & & & \\
\hline CU & .16 & .026 & $.27^{* *}$ & .36 & .13 & .12 & $18.69^{* *}$ \\
\hline MC & .11 & .035 & $.15^{* *}$ & & & & \\
\hline CF & -.09 & .033 & $-.12^{* *}$ & & & & \\
\hline COM & -.23 & .035 & $-.30^{* * *}$ & & & & \\
\hline Constant & $9.52^{* *}$ & & & & & & \\
\hline & & & & & & & \\
\hline
\end{tabular}

$* *=$ Significant at .01 level $*=$ Significant at .05 level

Abbreviations Used: UP - Union Power, OS - Outsourcing, MP-Management Power, UC - Union Characteristics measures, ULCC - Union Leader's Commitment and Competency, PA- Political Affiliation, ULA - Union leaders Attitude, IRC - Industrial Relations Climate, UNC - Union Cooperation, CU - Consultation, MC - Management Cooperation, CF-Confrontation, COM-Communication

While analyzing the power of management, it was found that leaders' commitment and competency $(\beta=-.17, \mathrm{p}<.01)$, political affiliation $(\beta=.14, \mathrm{p}<.01)$, and union leaders' attitude $(\beta=.10, \mathrm{p}<.01)$ had contributed significantly towards it, explaining 5 per cent of the variance $(F=11.97, p<.01)$. From these results, it can be said that the style of leadership adopted by union leaders had a bearing on the management power. If leaders are engaged in safeguarding the interest of the workers in real sense, this will definitely erode the power of the management. Leaders' commitment and competency was also found to have a negative effect. Since union leaders were engaged in seeking personal favours from the management, it could be said that lack of commitment towards the union increased the power of the management. Political affiliation of union has contributed positively towards the power of management. If a settlement is signed by the political leader on behalf of the trade union, the enforceability part was assured. However, union leaders have so far not changed their mindset and opposing attitude, which restricts the management power.

The results showed that four factors of industrial relations climate namely, management consultation of union by management $(\beta=.27, p<.01)$, management cooperation $(\beta=.15, \mathrm{p}<.01)$, confrontation $(\beta=-.12, \mathrm{p}<.01)$, and communication $(\beta=-.30$, $\mathrm{p}<.01)$ explained 12 per cent of the variance in the criterion measure $(\mathrm{F}=18.69, \mathrm{p}<.01)$. Cooperation from the management with the union might be due to economic recession, but by wining the support of union leaders management gained power. Consulting the unions in policy matters had not only helped in maintaining a healthy labour management relationship, but also helped in increasing production, and maintaining discipline among the workforce. Confrontation had also negatively influenced the power of the management. It seems that the 
present market scenario demands more cooperation between management and trade union for effective functioning of the organization. Communication was found to have a negatively impact on the management power. Withholding the information from unions was considered as a strategy to win over the bargaining table. But due to the inflow of information technology and increasing demand from unions, management is now compelled to share the information with unions.

The MRA result incorporating union characteristics factors as predictors and outsourcing as the criterion measure showed that union leadership $(\beta=.19, \mathrm{p}<.01)$, and union leaders' commitment and competency $(\beta=-.26, \mathrm{p}<.01)$ had contributed significantly towards outsourcing (see Table 13.1). These predictors altogether explained 8 per cent of the variance in the criterion measure $(\mathrm{F}=11.97, \mathrm{p}<.01)$. As leaders' commitment and competency has negatively contributed towards outsourcing, it can be argued that the lack of effort and strategy from the trade union leader has led to massive outsourcing in organizations. Trade union leaders did not take much interest to organize the contract and casual workers, whereas this section is increasing and becoming a pivotal part of the workforce. It is adding to the power of the management, as the onus of responsibility is on the contractor, not on the management. Few organizations were found to have trade unions for casual and contract labour, but they have not been able to come to the main stream. It was found that one organization had two separate unions, one for permanent workers, and the other one for contract labours affiliated to the same federation. It not only shows the multiplicity, but also the rivalry among themselves. Union leadership, and leaders' attitude towards workers had positively contributed towards the process of outsourcing. Trade union leaders had continuously been engaged in striving for power to satisfy their vested interest. Through dynamic leadership and positive attitude towards management union leaders can check the outsourcing in the organization.

Certain industrial relations climate factors emerged as significant predictors for outsourcing. These factors such as union cooperation $(\beta=-.26, p<.01)$, consultation $(\beta$ $=.28, \mathrm{p}<.01)$, management cooperation $(\beta=.13, \mathrm{p}<.01)$, and confrontation $(\beta=-.12, \mathrm{p}$ $<.01)$ explained 12 per cent of the variance in the criterion measure $(F=18.51, p<.01)$. The results also showed that management cooperation, and consultation had a positive impact on outsourcing, whereas union cooperation had a negative impact. Union cooperation with the management in resolving workplace issues, cutting down the labour cost, adopting concession bargaining, and accepting job cuts have increased outsourcing. Though cooperation, consultation and participation in the decision making process, management is trying to use unions a tool for handling workplace restructuring. Unions are instrumental in the process of voluntary retirement policy. The union leaders were either cooperating in implementation of this scheme, or keeping their mouth shut, indirectly helping the process of outsourcing.

\section{CONCLUSION}

The purpose of this article was to reassess the position of trade union in the era of globalization while adding the current trend to the literature. It seems that management never 
wanted to cooperate with the union. It may be the effect of the current economic situation. In the era of boom in the information technology, they can't hide the information, which was acting a source of power for them. Thus, this cooperation and disclosure of information is neither voluntary, nor helpful in maintaining a healthy labour management relationship. The workers and their representatives had not yet been allowed to actively participate in the decision-making process. Most of the time, they are just passing the information down the line after taking the decision. Otherwise, just to gain the support of the union, management consults them as and when necessary. They are still adopting the path of confrontation to retain their power. It has been seen that unions are now ready to leave the path of confrontation and cooperate with the management. But, confrontative attitude of the management still continues, and they strive to maintain their status. They are well aware about the facts that trade unions have become weak, and they will possibly not revive to compete with them. Outsourcing is considered to be the outcome of the current economic restructuring process. Earlier there was contract for the job, now the job itself is subcontracted. The 'job security' notion is disappearing day by day. It can be summarized that the power of the union is decreasing, and power of management has increased along with more and more outsourcing across organization.

Managers claimed that they took initiative for maintaining a better relationship with union through open discussion. The welfare measures provided by the organization were supposed to be adequate. But the leaders, as well as the workers had a low perception than the mangers in this regard, and considered that the welfare measures were not adequate enough for workers. They also believed that management victimizes active union workers, patronizes a particular union, and created rivalry among unions for their own benefit. Managers felt that union activities interfere with an employer's ability to run business, while union leaders, and workers rejected this fact. All the actors felt the necessity of the presence of union and their active role in maintaining a better relationship with workers. As there was no lockout in any of the organizations under survey, it indicated the management initiative to maintain union-management relationship. The strike was high in case of two organizations, where restructuring was in progress. In rest of the organizations, disputes were quite less showing a better industrial relations climate leading to a better union-management relationship.

Workers and union leaders believed that union power had decreased in post liberalized era. But the managers neither agreed nor disagreed over the issue. Both workers as well as the union leaders believed that union membership is decreasing day by day. Bargaining power of the union has also gone down. It has become difficult on the part of the union to go for a strike in this present market scenario. Management wanted to recognize a union and discuss all the matters of common interest with them. There is a significant difference among managers, union leaders, and workers that the outsourcing has increased in organizations. Number of casual workers has increased over the years in almost all the organizations. Casual labours, who joined the union did not have the voting right to elect the office bearers of the union, and the union also cannot raise an industrial dispute for them. It was also found that there were separate unions for contract labour under the same 


\section{Macrothink Institute ${ }^{T M}$}

undertaking affiliated to the same central federation. However, there is no doubt that casualisation has not only increased in organizations, but also negatively affected the strength of unions.

Union leaders perceived the functioning of the union as highly successful, whereas managers and workers did not agree with it. Union leaders perceived that unions were functioning effectively in all aspects such as securing better financial benefits, welfare measures, and working conditions for workers, resolving the grievances, maintaining discipline, educating workers regarding their rights and duties, and cooperating with management in improving productivity. Managers appreciated the union's performance with regard to financial benefits, but did not agree to the point that unions had helped in improving the productivity. Unions seldom tried to create a conscious workforce by educating them and improving their skill and efficiency. Workers were not satisfied with the achievement of the union leaders, as they could not even protect the prevailing benefits and services, which were being withdrawn by the management due to financial reasons. Though workers agreed upon the role of the union in protecting the workers form victimization by the management, they also admitted the failure of union in protecting their job.

This research is limited by the use of behaviuoral response from different actors of industrial relations excluding government. The major contribution is the study of workers and their leaders as separate actors. However, the secondary data like the number of strikes, lock outs, settlement signed, grievances raised and settled, numbers of wage hikes, pending court cases, number of disciplinary actions could have added value to the study. The findings of this study will definitely help the union leaders and management in preparing their future course of action. 


\section{REFERENCES}

Angle, H. L., \& Perry, J.T. (1986). Dual commitment and labour-management relationship climates. Academy of Management Journal, 29, 31-50.

Arya, P. P. (1982). Labour-management relations in public sector undertakings. New Delhi: Deep and Deep Publications.

Artz, B. (2010). The Impact of Union Experience onm Job Satisfaction. Industrial Relations, 49 387-405

Ashraf, M. S. (1974). Political affiliation of industrial workers- an area study. Indian Journal of Industrial relations, 10.

Aziz, A. (1974). Aspects of trade unionism in Karnataka. The Economic Times, Nov. 5.

Bhangoo, K. S. (1989). Industrial relations in cotton textile industry in Punjab. Unpublished Ph. D. Thesis, Punjabi University: Patiala.

Bhattacherjee, D. (1999). Organised labour and economic liberalisation - India: past, present and future. Discussion Paper, Labour and Society Programme. International Institute for Labour Studies, ILO, Geneva.

Borgrate, M. V. D. (1970). Trade unionism in Indian ports. New Delhi: Shri Ram Centre for Industrial Relations.

Chamberlain, N. W., \& Kuhn, J. W. (1965). Collective bargaining. New York: McGraw- Hill.

Chatterji, R. (1980). Unions, politics and the state- A study of Indian labour politics. New Delhi: South Asia Publishing.

Cheema, C. S. (1990). Industrial relations in public sector: A case study of Punjab Roadways. Unpublished Ph. D. Thesis, Guru Nanak Dev University, Amritsar.

Crouch, H. (1966). Trade unions and politics in India. Bombay: Manaktalas.

Das, G. S. (1985). Some aspects of union involvement of the bank employees. Decision, 12.

Das, P. C. (1990). Trade union and politics in India. New Delhi: Discovery Publishing House.

Dastmalchian, A, Adamson, R., \& Blyton, P. (1986). Developing a measure of industrial relations climate. Industrial relations, 41, 4, 851-859.

Dayal, I., \& Sharma, B. R. (1970). The strike of supervisory staff in state bank of India. Bombay: Progressive Corporation.

Deery, S., Erwin, P., \& Iverson, R. (1994). Predicting organizational and union commitment: the effect of industrial relations climate. British Journal of Industrial Relations, 32, 581-597.

Deery, S., Erwin, P., \& Iverson, R. (1999). Industrial relations climate, attendance behaviour and the role of trade unions. British Journal of Industrial Relations, 37, 533-558.

Fiedler, F. E. (1967). A theory of leadership effectiveness. New York: McGraw-Hill.

Finkelstein, S. (1992). Power in top management teams: dimensions, measurement and validation. The Academy of Management Journal, 35.

Foneseca, A. (1965). Contribution of the trade unions to development. Indian Journal of Industrial Relations, 4. 
Gani, A. (1988). Labour-management relations in textile industry of Jammu and Kashmir state since 1971. Unpublished Ph. D. Thesis, University of Kashmir: Srinagar.

Goodman, J. ((1989). Industrial relations and restructuring in manufacturing: three case studies in the United Kingdom. International Labour Review, 128, 601-619.

Guest, D. E. (1989). Human resource management: its implications for industrial relations and trade unions. In J. Storey (ed.), New Perspectives on human resource management. London: Routledge.

Guest, D. E., \& Dewe, P. (1991). Company or trade union: which wins workers' allegiance? A study of commitment in the UK electronics industry. British Journal of Industrial Relations, 29, 75-96.

Hair, J. F. (Jr.), Anderson, R. E., Tatham, R. L., \& Black, W. C. (1995). Multivariate data analysis. New Jersey: Prentice Hall.

Heckscher, C., \& Schurman, S. (1997). Towards jobs and justice: can labour-management cooperation deliver jobs and justice? Industril Relations Journal, 28.

Huszczo, G.E. \& Hoyer, D.T. (1994). Factors involved in constructive union-management relationships. Human Relations, 47, 7, 847-866.

Karnik, V. B. (1966). Indian trade unions -A survey. Bombay: P.C. Manekalal and Sons.

Katz, H. C., Kochan, T. A., \& Gobeille, K. R. (1983). Industrial relations performance, economic performance, and QWL programs: an interplant analysis. Industrial and Labour Relations Review, 37, 3-17.

Mamkootam, K. (1977). Factionalism and power in trade unions: a case study. Indian Journal of Industrial Relations, 13, 167-190.

Mamkootam, K. (1982). Trade unionism myth and reality: unionism in the Tata Iron and Steel Company. Delhi: Oxford University Press.

Masilamani, S. (1992). Power game in industrial relations: A study of a south Indian organisations. Center for Management Development, Modinagar (Mimeo).

Masilamani, S. (1993). Industrial restructuring and union-management power dynamics: a case study. Indian Journal of Industrial Relations, 29, 191-205.

Mital, R. A. (2001). Role of trade unions: some random thoughts. Indian Journal of Industrial Relations, 37, 176-180.

Modi, S. (1995). Dynamics of trade unionism: perceptions and attitudes of workers, union leaders and management. New Delhi, Deep and Deep Publications.

Monga, M. L. (1978). The worker speaks his mind: a study of company and union allegiance. Indian Labour Journal, 19, 859-864

Nulty, P. (1993). Look what the unions want now. Fortune, Feb.

Pandey, S. M., \& Vikram, C. M. (1969). Trade unionism in Delhi's building industry. Indian Journal of Industrial Relations, 4, 298-321.

Parmar, J. S. (1997). Some emerging dimensions of trade unionism in HRTC: An empirical approach. Indian Journal of Industrial Relations, 32, 328-344.

Patel, S. (1998). Work and workers in Mumbai, 1930s-90s: Changing profile, enduring problems. Economic and Political Weekly, November 14.

Pattabhi, R. N. (1967). Political involvement of India's trade unions: A Study of the anatomy of the political labour movement in Asia. Bombay: Asia Publishing house. 
Pattnaik, S. P. (1993). Strike: A study of conflict. New Delhi: Gyan Publishing House.

Pillai, K. M. (2000). Labour and industrial laws. Allahabad: Law Agency.

Purcell, J. (1991). The rediscovery of the management prerogative: the management of labour relations in the 1980s'. Oxford Review of Economic Policy, 7, 33-34.

Pyman, A., Holland, P., Teicher, J, and Cooper, B.K. (2010). Industrial Relations Climate, Employee Voice and Managerial Attitudes to Unions: An Australian Study.British Journal of Industrial Relations, 48, 460-480.

Ramanujam, G. (1967). From the babul tree: story of Indian labour, Delhi: I.N.T.U.C.

Ramaswamy, E .A. (1977). The worker and his union- A study in South India. Bombay: Allied Publishers.

Ramaswamy, E. A. (1999). Worker co-operatives in India: Lessons from Kamani. Economic and Political Weekly, XXXIV.

Rao, M. M. (1986). Labour management relations and trade union leadership. New Delhi: Deep and Deep Publications.

Reddy, D. N. (1972) .The impact of political party trade union nexus on bargaining power in public employment: A case study. Indian Journal of Industrial Relations, 1, 121-130.

Sengupta, A. K. (1992). New generation of organised workforce in India: implications for management and trade unions. In J.S. Sodhi and S.P.S. Ahluwalia (eds). Industrial relations in India: The coming decades. New Delhi: Sri Ram Centre for Industrial Relations and Human Resources.

Sherlock, S. (1989). Railway workers and their unions. Economic and Political Weekly, XXIV, 2311-22.

Sheth, N. R. (1969). Workers' participation in union activity. Indian Journal of Industrial Relations, 4, 279-97.

Sheth, N. R. (2001). Trade union in word and deed. Indian Journal of Industrial Relations, 37, 280- 284.

Singh, J. (1980). India's trade union leaders. New Delhi: National.

Singh, M. (1990). The political economy of unorganised industry. New Delhi: Sage Publications,

Sinha, C. (2001). Role of trade unions in developing a culture of high performance. Indian Journal of Industrial Relations, 37, 181-185.

Sinha, D., \& Paul, M. V. (1963). Motivational analysis of union membership. Indian Journal of Social Work, 23, 343-49.

Sood, S. (1984). Trade union leadership in India. New Delhi: Deep and Deep Publications.

Subramanian S., \& Rao, K. S. (1997). Attitudes of union leaders in changing realitiesdirection towards greater involvement. Indian Journal of Industrial Relations, 32, 409-422.

Thakur, C. P., \& Munson, F. C. (1969). Industrial Relations in Printing Industry: A Study in the context of technology and market in Delhi area. New Delhi: Sri Ram Center.

Tulpule, B. (1990). Trade unionism: problems for the nineties. Indian Journal of Social Work, LI, $273-77$.

Vaid, K. N. (1965). Trade unions in India. New Delhi:.Shri Ram Centre. 
Witte, H. D. , Sverke, M. , Ruysseveldt, J.V., Goslinga, S., Chirumbolo, A., Hellgren, J., and Naswall, K. (2010). Job Insecurity, Union Support and Intension to Resign Membership: A Psychological Contract Perspective. European Journal of Induatrial Relations. 14, 85-103.

Zullo, R. (2008), Union Membership and Political Inclusion. Industrial and Labour Relations review, 62, 22-38 